\title{
URBAN WATER SUPPLY REQUIREMENT UNDER AMRUT PROGRAM
}

\section{UMESH HOLE $^{1} \&$ ANIKET PATHADE ${ }^{2}$}

\author{
${ }^{I}$ Ms. C.S. Waghmare, YCCE, Nagpur
}

${ }^{2}$ Research Scientist, Jawaharlal Nehru Medical College, Datta Meghe Institute of Medical Sciences, Sawangi, Wardha, India

\begin{abstract}
ABSTACT
Potable water is becoming scarcer; often making it more energy intensive to procure. More energy is required to pump water to greater distances and from deeper depth in the ground. This alarming situation and ever increasing population has cautioned everybody to conserve the available water resources and adapt oneself to optimum use of available water. The water supply, being an essential commodity, has to be looked upon from demand side as well as supply side ${ }^{1,2}$. The urban local bodies, which are from the supply side, will have to play vital role in managing this often-scarce resource. As global urbanization continues, they have the complex task of cost effectively providing water to keep cities functioning further in the process of improving overall water system efficiency, energy \& water consumption have to be viewed as linked inputs rather than viewing them as separate and unrelated. On the other hand, the demand side which consists of consumers has to be made aware of the present situation of the available water resources, necessary habitual changes required to be made by adopting various means of water conservation, optimal use of available water, re-used and recirculation of waste water for some activities ${ }^{3,4,5}$.

KEYWORDS: Urban Water, Water Conservation, Pump Water \& Amrut Program
\end{abstract}

Received: Jun 09, 2020; Accepted: Jun 29, 2020; Published: Aug 11, 2020; Paper Id.: IJMPERDJUN2020715

\section{INTRODUCTION}

Overall study of the water supply scheme with recommendations as per reform activity will help the system to run in sustainable way throughout the working as per design ${ }^{6,7}$. Designer has to face challenges while designing the water supply scheme also team responsible for operation and maintenance of the scheme faces challenges to run the system; the basic reason for this if unavailability of the base data for decision making. Some of such problems can be listed below, 
Table 1

\begin{tabular}{|c|l|l|}
\hline $\begin{array}{c}\text { Sl. } \\
\text { No. }\end{array}$ & \multicolumn{1}{|c|}{ Challenges in DPR Preparation } & \multicolumn{1}{c|}{ Solutions using Technology } \\
\hline 1 & $\begin{array}{l}\text { Demand Allocation - Domestic, institutional and } \\
\text { commercial demand allocation }\end{array}$ & Demand allocation is as per consumer Survey data \\
\hline 2 & Determination of pipe size & By correct demand allocation for forecasted scenario \\
\hline 3 & $\begin{array}{l}\text { Attributes of proposed features need to be confirm } \\
\text { from ground before estimation }\end{array}$ & $\begin{array}{l}\text { GIS based maps and drawing can give ready abstract of } \\
\text { proposed scheme }\end{array}$ \\
\hline 4 & $\begin{array}{l}\text { Assumption about existing infrastructure to be } \\
\text { retained in the proposed scheme }\end{array}$ & $\begin{array}{l}\text { Study of each component can help in decision to retain or } \\
\text { replace. }\end{array}$ \\
\hline 5 & C value of existing pipes is generally assumed & $\begin{array}{l}\text { Calibration of existing system model can give 'C' value for } \\
\text { design. }\end{array}$ \\
\hline 6 & No proper zoning is observed & $\begin{array}{l}\text { Formation of District metering areas as per ESR/GSR } \\
\text { command areas can be done }\end{array}$ \\
\hline 7 & Inequitable water supply & $\begin{array}{l}\text { Elevation model is studied and zoning is done considering } \\
\text { assured residual pressure at all the nodes of model. }\end{array}$ \\
\hline 8 & Preparation of report and DPR & $\begin{array}{l}\text { we can prepare the graphical as well as thematic } \\
\text { representation of study area to prepare a report presentable }\end{array}$ \\
\hline
\end{tabular}

\section{Benefits of Reform Activities}

- Capability of existing system can increase.

- $\quad$ Non-revenue water can be minimized.

- Water quality \& quantity can be improved.

- Immediate and proper water supply services can be provided to the consumers.

- The expenditure on modification of existing water supply system can be avoided or can be differ.

- Revenue can be increased by converting illegal connection into legal connections.

- $\quad$ Existing water supply scheme can be optimized and controlled in proper manner.

These reform activities can be further subdivided in various activities such as, carrying out consumer survey, Geographic Information System (GIS) development \& mapping, hydraulic modeling,water audit, energy audit etc ${ }^{8,9}$.

\section{A) Consumer Survey}

- Collecting data regarding size and type of connections and usage of water.

- Collecting number of Consumers \& Consumer types.

- Collecting information regarding illegal connections.

- Socio Economic condition of the consumers.

\section{B) G.I.S. Mapping}

- $\quad$ Preparation of GIS base map of city and marking of various features related to assignment.

- Various maps representing Status of Connections, Type of Connection, Legal/Illegal connections etc.

\section{C) Hydraulic Modeling}

- Preparing a hydraulic model for existing scenario \& proposed scenario for equitable distribution of water by 
pressure.

- Finding and suggesting improvements to the technical deficiencies in the water distribution system.

- $\quad$ Suggest suitable rehabilitation.

\section{D) Computerized Water Billing System}

- Computerization of water billing to avoid human errors.

- $\quad$ Preparation of database of consumers in water supply system.

- Water bill preparation with the help of meter reading.

- $\quad$ Preparing reports about various water tariffs.

\section{E) Flow Meter Installation}

- Installing bulk flow meters at appropriate location to know the exact amount of water lifted from the source, treated in the plant, inflow \& out flow at various components and distributed to consumer in the town.

- Comparison of demand and supply using actual measurements

- Conducting Leak detection program and monitor NRW

\section{F) Water Audit}

- Collecting data regarding water lifted and supplied from the source/s, inflow \& out flow of each components and water consumed by consumers.

- $\quad$ Detecting the water losses and thefts.

- Calculation of non-revenue water (NRW).

- $\quad$ Suggest suitable measures to monitor \& rectify the same.

\section{G) Energy Audit}

- Calculating the efficiency of power supply \& existing pumping machinery.

- Finding the difference between standard efficiency and the calculated efficiency.

- $\quad$ Suggest suitable measures to improve the efficiency.

- Analysis of existing power factor and measures to maintain unity.

\section{H) Automation}

- Identification of the components which can be automated

- Comparison between manual and automated operation in terms of investment and cost required to run the system

- $\quad$ Pay back analysis for investment

- Introduction to new edge technologies based on GSM and GPRS technologies 
- $\quad$ Pump operation, Valve operation, treatment processes and quality checking can be aimed for automation.

Results of all the activities of water supply reforms are then required to be clubbed together to create a comprehensive decision making platform to propose the scheme in futuristic approach.

Data of Consumer Survey will give us the precise demand of present stage; using this as a base data we can forecast the demands using area proportion method. We can also ensure the demand of bulk, institutional, industrial and commercial connections so that the pipe sizes will be optimized for design stages ${ }^{10,11}$.

GIS mapping will give correct attributes of the proposed features of water supply like length of proposed pipes, location of Head work, treatment plant, pumping station and storage reservoirs. Integrated maps of land use, land cover, consumer data, water supply assets and total station data (contours) will give a strong ground to designer to optimize the existing infrastructure and propose the best for forecasted scenarios.

Energy audit is also a very important process of reform activity. Results of energy audit can focus to optimize electrical efficiencies of pumping station. Recommendation can help in utilization of existing pumping machinery with minimal level of investments. Calculation of power factor and Time of Day (TOD) can also help a system to get incentivized from electricity distribution companies. All these observation can be a part of final proposed scheme components.

Water Audit study is basically aimed for calculation of NRW of the system. All the sections of water supply system including raw water transmission, treatment, pure water transmission and distribution are studied for both water losses and revenue losses. Study of consumption pattern of all type of consumers is done and their analysis can be used for proposing new tariff structure. Application of telescopic tariff and charges of metered consumption can be calculated to reach up to the comprehensive plan of operation and maintenance. Study of distribution system can also give a decision making data to replace existing AC/PVC and old metallic pipes ${ }^{12}$.

All the critical recommendations from all these activities will be an added input to the Hydraulic Modeling. Forecasting of population, estimation of demand, allocation of demand using modern software can assist the modeler in preparation of better scheme design. Inputs from consumer survey will help to allocate demand at the nearest node in existing scenario and admin boundaries from GIS will help to area wise allocation of demand for design of ultimate stage scenarios. Contour data derived from total station survey is required to design head of pumping machinery, staging height of service reservoirs to ensure desired residual pressure at consumer end. Hydraulic modeling is based on GIS platform so we can have ready data of proposed scheme. We can directly extract the abstract from software for preparation of estimates and also can print working maps ${ }^{13}$. Calibration of the model with ground condition is done to fix the $\mathrm{C}$ value of existing pipes.

Overall, all these activities involves a detailed study of entire water supply scheme; which can create a base for decision making and aid as working hand to the designer. Besides this we can prepare the graphical as well as thematic representation of study area to prepare a report presentable before appraisal committee.

\section{REFERENCES}

1. ADaRSH. (2016a) (2016b) (2016c) (2016d) (2016e). Association for Development and Research of Sustainable Habitats. 
2. Akudinobi, B. E. B., and C. M. Okolo. "Qualiitive Evaluation of Urban Water Sources in Onitsha Area of Anambra State, Nigeria." (2012).International Journal of Environment, Ecology, Family and Urban Studies (IJEEFUS) 3. 1, Mar 2013, 35-44

3. Ashok, Gaikwad Sonali. "Water Anti-Theft and Quality Monitoring System by Using PLC and SCADA." International Journal of Electrical and Electronics Engineering Research 3.2 (2013): 355-364.

4. Batra, L. (2009). A review of urbanization and urban policy in post-independent India. Working Paper Series, Centre for the Study of Law and Governance. Jawaharlal Nehru University, New Delhi.

5. Brueckner, J. Urban sprawl: Diagnosis and remedies. International Regional Science Review. 2000; 23(2), 160-171.

6. Dehalwar, K. A. V. I. T. A., and J. A. G. D. I. S. H. Singh. "Current State of Water Management System: Case Review of Bhopal, Madhya Pradesh." International Journal of Civil, Structural, Environmental and Infrastructure Engineering Research and Development (IJCSEIERD) 5.6 (2015): 35-40.

7. Gnaneshwar, V. Urban policies in India-Paradoxes and predicaments. Habitat International. 1995; 19(3), $293-316$.

8. GOI. (n.d.a). Amrut Yojana. Atal Mission for Rejuvenation and Urban Transformation. http://amrut.gov.in/.

9. GOI Census of India. (2011). Population enumeration data.

10. Gupta K. Urban flood resilience planning and management and lessons for the future: A case study of Mumbai, India. Urban Water Journal. 2007; 4(3): 183-194.

11. IIHS. (2012). Indian Institute for Human Settlements. Urban India 2011.

12. Levine A, Asano T. Recovering sustainable water from wastewater. Environmental Science and Technology, 201A-208A: 2004.

13. McKenzie D, Ray I. Urban water supply in India: Status, reform options and possible lessons. Water Policy. 2009; 11(4), 442460.

14. Nandi S, Gamkhar S. Urban challenges in India: A review of recent policy measures. Habitat International. 2013; $39:$ 55-61.

15. Sahni S, Aulakh, R. Planning for low carbon cities in India. Environment and Urbanization Asia. 2014; 5(1), 17-34.

16. Sankhe S, Vittal I et al. Urban giants India and China, and their urbanization paths. Environment and Urbanization Asia. 2011; 2(1), 1-12.

17. Sharma, Mahima. "Study of High Fluorides in Ground Water Resources of KeshoraiPatan and Its Health Aspects." International Journal of Environment, Ecology, Family and Urban Studies (IJEEFUS) ISSN (P) (2016): $2250-0065$. 
